\title{
Outbreak of Corona Virus, Ocular Involvement and Scenario in Nepal
}

\author{
Raju Kaiti ${ }^{1 *}$, Ranjila Shyangbo ${ }^{2}$, Manish Dahal ${ }^{3}$ and Bishal Hamal ${ }^{3}$ \\ ${ }^{1}$ Consultant Optometrist, M. Optom, Nepal Eye Hospital, Kathmandu, Nepal \\ ${ }^{2}$ Optometry student, 3rd year, B. Optom, National Academy of Medical Sciences, \\ Kathmandu, Nepal \\ ${ }^{3}$ Consultant Optometrist, B. Optom, Nepal Eye Hospital, Kathmandu, Nepal \\ *Corresponding Author: Raju Kaiti, M. Optom, Consultant Optometrist, Nepal Eye \\ Hospital, Kathmandu, Nepal. E-mail: rajukaiti@gmail.com
}

\author{
Received: March 20, 2020 \\ Published: April 17, 2020 \\ (C) All rights are reserved by Raju Kaiti., et al.
}

\begin{abstract}
Coronavirus disease (COVID-19) originating in the Chinese city of Wuhan has rapidly emerged as a global health threat. It is anticipated that over 186 countries have been affected, with Nepal being one of the countries at major risk. Nepal reported its first case on 13th January 2020. The novel corona virus 2019 (2019-nCoV) has sparkled global concern but the route of its transmission has not yet been elucidated fully. It is believed to be mainly respiratory. There have been anecdotal reports of ocular transmission. No cases of ocular transmission has been reported in Nepal. Nepal government lacks enough kits for rapid screening. Till date, Nepal is only one country marked Green for Corona virus. It is important for government to to be responsible enough to suppress the cases of COVID-19, prevent transmission and to make necessary arrangements, identify, diagnose cases, isolate and quarantine.
\end{abstract}

Keywords: Coronavirus disease, Global health, Nepal, Ocular transmission

Outbreak of the novel coronavirus, following the first report from Wuhan, China on late December 2019 has been declared as a Public Health Emergency of International Concern on $30^{\text {th }}$ January 2020 by WHO [1]. Till date 285,699 confirmed cases have been reported, tolling 11,875 deaths and 93,584 recoveries, as reported by WHO. It is anticipated that over 186 countries have been affected, with Nepal being one of the countries at major risk. Nepal reported its first case on $13^{\text {th }}$ January 2020, who had a mild grade infection and later was discharged following complete recovery [2].

The novel corona virus 2019 (2019-nCoV) has sparkled global concern but the route of its transmission has not yet been elucidated fully. The origin of the virus remains unknown, and the virus-host is suspected to be a species of bat [3]. It is believed to be mainly respiratory. However, anecdotal reports suggest the virus can cause conjunctivitis and possibly be transmitted by aerosol contact with conjunctiva. This is where the eye care professionals need to be cautious about the outraging pandemic.

Eye as a possible route for transmission of 2019-nCoV was suspected when Dr. Wang Guangfa [4] of Perking University was diagnosed with coronavirus following an acutely inflamed left eye. He reported that the eye infection was followed by fever and built up of mucus in his throat and nose. He believed that he might have caught virus as he had not protected his eyes, though he had worn a N95 mask [4]. Dr. Jan Evans Patterson of Long School of Medicine's infectious diseases division at UT Health San Antonio, confirms that a scenario like Wang's potentially could happen [5]. Dr. Stephen Thomas of SUNY Upstate Medical University in Syracuse, New York believes that the hand to eye spread can be "plausible but unlikely" [5].

Infectious droplets and body fluids can easily contaminate the human conjunctival epithelium [6]. Respiratory viruses are capable of inducing ocular complications in infected patients, which then leads to respiratory infection. The fact that exposed mucous membranes and unprotected eyes increased the risk of coronavirus transmission suggests that exposure of unprotected eyes to 2019$\mathrm{nCoV}$ could cause acute respiratory infection. Saying these, since viral and allergic conjunctivitis are more common in this season, every conjunctivitis might not be secondary to corona infection. So, if conjunctivitis is associated with other symptoms of runny nose, sore throat,cough, fever, difficulty breathing (severe cases), prompt medical care is important. Given that COVID-19 patients may present to the hospital with viral conjunctivitis, it would be wise to question patients directly if they had any symptoms and signs of conjunctivitis prior respiratory and other systemic symptoms to help further our understanding of the history of the disease. 
In Nepal, so far only 1 case has been reported among 212 tested $[2,7]$. If the situation of COVID-2019 in Nepal is to be analyzed, Nepal, by far has been successful in containing its first case, alongside preventing its spread. This can be attributed to the immediate containment of the suspect and timely precautions taken by the government and the concerned authority itself. Postpone of "Visit Nepal 2020" by Nepal government amidst COVID-2019 could be one of the contributing factors. So far more than 400 Nepalese has been tested for COVID-2019, of which all of them were negative, except for the infected case. Nepal government has announced closure for non- essential services and decided to donate 100 Million for SAARC's Emergency Fund to fight COVID-2019. Also, the travel restrictions from different affected countries alongside strict monitoring of body temperature itself in the international and national airport of Nepal has played a pivotal role. Any person who has returned from abroad recently should stay in self-isolation for 14 days as per Nepal Government. All the necessary prerequisites for battling COVID-2019, which includes the trained health care professionals, isolation wards, ventilators, medications and environment has been made ready in different part of Nepal, if any cases are to be found. Nepal is only one country marked Green till today for Corona virus. But it can change overnight as still many people are not taking it seriously. They are moving here and there without any protective masks; public vehicles are overcrowded; public are still engaging in religious gathering, picnics and festivals. These irresponsible activities of Nepalese might make them pay huge price in near future. With days passing, availability of masks is not easy, sanitizers are out of stock and movement of public away from Kathmandu is high. All these constraints and irresponsible activities might change the green zone to red zone.

While such an effort is a crucial response to tackling the crisis, understanding of the virus's transmission patterns still remain murky. Whilst the aerosol transmission is at the highlight, transmission by ocular surface must not be ignored. Therefore, eye care professionals must be aware of this plausible method of transmission. Travel restriction adherences, personal and environmental sanitation, as well as awareness by keeping updated on global spread are also very essential [8].

A very clear cut strategic plan is the need of the hour. Federal government, province and local government needs to be responsible at this critical period. The main strategy should be to suppress the cases of COVID-19, prevent transmission and in the mean time to make necessary arrangements, identify, diagnose cases, isolate and quarantine. WHO has stressed the key strategy and only strategy is: Testing, Testing and Testing. So, this is the very important for Nepal Government to purchase kits enough for rapid screening. So far the government has only bought some PCR machines and test kits. This will delay screening. Government and stakeholder need to be prepared for this threat and take concrete steps to deal with the crisis.

\section{References}

1. WHO. "Statement on the second meeting of the International Health Regulations (2005) Emergency Committee regarding the outbreak of novel coronavirus (2019-nCoV)" (2020). [Internet].[cited 2020 March 2]

2. Anup Bastola., et al. "The first 2019 novel coronavirus case in Nepal”. Lancet Infectious Diseases 20.3 (2020): 279-280.

3. Zhang L., et al. "Origin and evolution of the 2019 novel coronavirus". Clinical Infectious Diseases (2020): ciaa112. [Internet]. [cited 2020 March 2]

4. Dai X. "Peking University Hospital Wang Guangfa disclosed treatment status on Weibo and suspected infection without wearing goggles". [Internet].[cited 2020 March 2]

5. John Egan. "Coronavirus: How eyes may play a role in its spread". [Internet].[cited 2020 March 2]

6. Olofsson S., et al. "Avian influenza and sialic acid receptors: more than meets the eye?" Lancet Infectious Diseases 5.3 (2005): 184-188. [Internet].[cited 2020 March 2]

7. Health Emergency Operation Center, Health Emergency and Disaster Management Unit (HEDMU), Ministry of Health and Population, Government of Nepal. Heoc.mohp.gov.np. (2020). Resource materials on Novel coronavirus (2019-nCoV) Health Emergency Operation Center. [cited 2020 March 2]

8. Isawumi Michaeline Asuquo. "Corona Virus- Facts Today! Unknown Tomorrow?” EC Ophthalmology 02 (2020): 1-5.

\section{Assets from publication with us}

- Prompt Acknowledgement after receiving the article

- Thorough Double blinded peer review

- Rapid Publication

- Issue of Publication Certificate

- High visibility of your Published work

Website: www.actascientific.com/

Submit Article: www.actascientific.com/submission.php Email us: editor@actascientific.com

Contact us: +919182824667 